\title{
Is Negotiation a threat to Zimbabwean investment deals? an analysis of essar and green fuel investments
}

\author{
Michael Musanzikwa \\ Lecturer at Chinhoyi University in the Department of Supply Chain Management
}

\section{Email address:}

michaelmusanzikwa@yahoo.co.uk

\section{To cite this article:}

Michael Musanzikwa. Is Negotiation a Threat to Zimbabwean Investment Deals? an Analysis of Essar and Green Fuel Investments. Journal of Investment and Management . Vol. 2, No. 3, 2013, pp. 41-49. doi: 10.11648/j.jim.20130203.12

\begin{abstract}
Purpose: The purpose of this paper is to provide an overview of the Negotiation structures in Zimbabwe, addressing the extent to which negotiation mechanisms may have been a contributory factor to the recent negotiated government deals with Essar and Green Fuel Chisumbanje projects which have taken so long to take off than as anticipated. Design/Methodology/Approach: The study adopted a qualitative research design because it provided flexibility and afforded the researcher the opportunity to conduct an in-depth research. Case studies of Essar and Green Fuel investments were conducted. Findings: The findings suggest that there were no effective stakeholder consultations before the FDI deal with Essar was signed. It appears as though negotiators were in a hurry to sign the agreement before doing a thorough analysis. The case of Green Fuel, also demonstrated the absence of wider stakeholder consultation before the implementation of the project. There was evidence of lack of transparency on the part of negotiations. Research Limitations/Implications: The main limitation of the study lies with a lack of complex analysis undertaken to support the findings. Practical Implications: The findings from the study suggest that Government policy is never implemented Social Implications: Governments across the world pay lip service when it comes to implementing Government projects. As a result the public suffer due to poor service delivery. Originality/Value: The paper is original as it is the first attempt to discuss government negotiation deals that do not materialise according to the planned time frame.
\end{abstract}

Keywords: Foreign Direct Investment, Negotiation, Public Policy, Projects

\section{Introduction}

This research focused on two negotiated government investment deals namely the Essar and the Green Fuel Chisumbanje Projects which have taken so long to take off to the anticipation of the beneficiaries. The public was concerned as to why these negotiated deals have taken so long while the contracts were sealed and approved and the obvious answer lies on negotiation. This was because government of Zimbabwe delayed the fulfilment of the contracts based on the wishful thinking that "if I had known what I know now I could not have entered or negotiated the deal". This means that there were some anomalies into the way the contracts were handled and this threatened the viability of the contracts.

The Essar deal was entered into by the Government of Zimbabwe through the Ministry of Industry and Commerce with Indian company Essar Holdings with the intention of resuscitating the former Zimbabwe Iron Steel Company
(ZISCO). This deal gave birth to the New Zim Steel Limited with Essar Company Holding getting 54\% stake. However, in 2012, the deal came to a standoff with the Zimbabwean Ministry of Mines and Mining Development being reluctant to hand over the mining claims, claiming that, firstly, it was not involved in the negotiation of the deal and, secondly, that the mineral claims by Essar should have included only those belonging to ZISCO and its subsidiaries not to include mineral claims outside its signed agreement. Thirdly initially the deal structure was 60-40 percent in favour of the Essar but in 2012, records showed that the NewZim Minerals had 80-20 percent shareholding structure in favour of Essar.

The Ministry of Mines and Mining Development was surprised by the sharing structure of the deal because it felt that its mandate was being compromised since as a Ministry its duty was to protect Zimbabwe's mineral resources for future generations. On the other hand the Ministry of Industry and Commerce's response was that the Mines and Minerals Act did not provide for valuation minerals before 
a licence could be granted. As a result, the negotiated investment deal came to a standstill with the Ministry of Mining and development requesting the deal to be revisited because the Indian Company was only going to pay US\$ 700 million for resources worth over US\$ 30 billion. Based on those facts the Ministry of Mines reported that it was not going to surrender the minerals to Essar for no value in return. In addition to that some relevant stakeholders were supporting the view of the Ministry of Mines that the deal should be revisited because Zimbabwe sold the processing plant and iron deposits for too little. Some were of the view that proper procedures were not followed in the first place and certain issues were not done above board hence the support to have the deal renegotiated. As a matter of fact, the Essar investment shows that negotiation can be a threat to contracted deals if it is not handled properly.

The Chisumbanje Green Fuel Ethanol deal is the other project which was entered and approved by the government with its private partner and it failed to take off with the government reporting that it no longer wanted to utilise the product. In May 2012, it was reported in the local media that the parties to the deal were yet to agree on the outstanding issues concerning the structure of the fundamentals of the deal despite the fact that the deal was already negotiated and approved. In addition to that the government was said to be backtracking on the initial Build Operate and Transfer (BOT) agreement in the ethanol project claiming that the government had now realised how it was being shot changed in the BOT structure, thereby delaying further the take off of the project deal.

Some stakeholders were of the view that the Green Fuel Deal should be revisited so that it can be a joint venture instead of a partnership although sitting the unavailability of capital to fund the deal on a joint venture basis. The derailment of the project to take off showed some serious shortfalls of how a proper negotiation deal should have been handled or conducted from a professional point of view. This is because the way these two deals were negotiated proved to be a threat to the viability and prosperous investments which were going to contribute positively to the growth of the economy. The government lamented to the reactions of its actions now requesting the negotiated deals to be re-looked or be re-visited. The major weakness in these contracted deals was that the negotiating team on behalf the government lacked expect knowledge of how to handle negotiation. As a result the writer is here to share some views as to how to handle or overcome some of the anomalies resulting from a negotiation process.

\section{Research Objective}

The researcher sought to attain a number of objectives. These were;

To analyse the importance of negotiation in FDI deals

To evaluate the negotiation processes for Essar and Green Fuel Projects

To come up with strategies for improving negotiation for
FDI in Zimbabwe.

\section{Literature Review}

\subsection{Definition of Key Terms}

Foreign Direct Investment: This is when foreign companies or individuals come to do business in a host country.

Negotiation: Negotiation is the process of planning, reviewing and analysing used by the buyer and seller to reach acceptable agreements or compromise and these agreements and compromises include all the aspects the business transactions, not just price.

\subsection{Conceptual Framework}

Negotiation and FDI were the main variables in this study and there was an analysis of the relationship between negotiation and good FDI projects. Negotiation was the independent variable while FDI projects were dependent variables. There were also intervening variables like transparency, stakeholder consultation, and adequate analysis of investment deals. Figure 1 illustrates the conceptual framework.

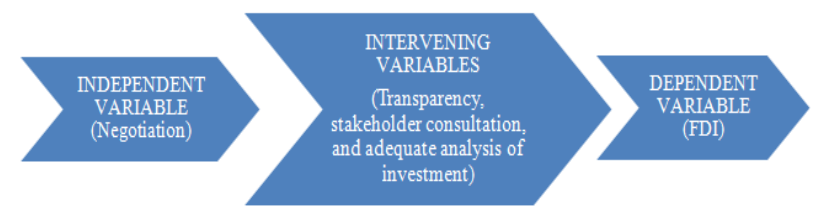

Figure 1. Conceptual Framework.

This study looked at the relationship between negotiation and successful FDI deals in country. If a host country has good negotiators, there would be high chances for a winwin situation in FDI projects.

\subsection{What is Negotiation?}

According to Hilltop and Udall (2008), negotiation is an interactive process aimed at a fair, reasonable and mutually acceptable outcome between two or more parties involved in a bargaining process. Negotiation has essential characteristics and these are:

It is between two or more parties with different opinions or viewpoints.

It reconciles differences between the parties involved.

The outcome of negotiation is dependent, at least in part, on the perceived relative power relationship between participants, through perceptions of power inequality undermine trust, inhibit dialogue and decrease the likelihood of a constructive outcome (Moss, Ramachandran, and Shah, 2008).

Both sides / parties need to make concession in order to move towards an agreement.

The end stages of negotiation are particularly delicate, with private discussions closing the gap between the parties.

Personalities and their interactions can affect negotiating 
outcomes.

Negotiation entails that other parties influence the decision of one party.

\subsection{Steps in Negotiating}

Hilltop and Udall (2008) point out that there are four main steps in negotiation. These are preparation, opening the encounter, problem solving, and agreement or disagreement.

\subsubsection{Preparation}

Negotiators prepare a counter attack, attack, defence, and initiative. This stage involves agreeing on the agenda, data collection and analysis, and determining objectives, strategy and tactics.

\subsubsection{Opening the Encounter}

Stating of the case and clarification of the opposition's position dominates this stage. It is also the 'dialogue of the deaf' or 'challenge and defiance', because negotiators appear to be ignoring the arguments of the other party and concentrate on presenting their own case. This is a stage where negotiators are required to be firm and clear.

\subsubsection{Problem Solving}

The main objective of the negotiator here is to use information, arguments and counter arguments in order to change the attitudes of the other party and identify a secure and mutually acceptable agreement. The following tactics can move the other party closer to one's position.

\subsubsection{Aggressive Tactics}

The negotiator threatens withdrawal from negotiations completely unless the other party adopts a realistic attitude or position. Imposing a deadline (ultimatum) for the other party to agree and threatening serious consequences for the other party.

\subsubsection{Conciliatory Tactics}

Emphasize gains to both parties and offer something in the process.

\subsubsection{Parties Agree Or Disagree}

Both parties sign the agreement and it becomes a binding contract. A disagreement is not desirable in the context of negotiation and can indicate a continuation or restart of the negotiations.

\subsection{Role of Foreign Direct Investment in Africa}

According to Akingube (2008), in the face of inadequate resources to finance long-term development in Africa and with poverty reduction and other Millennium Development Goals (MDGs) looking increasingly difficult to achieve by 2015, attracting FDI has assumed a prominent place in the strategies of economic renewal being advocated by policy makers at the national, regional and international levels. FDI can play an important role in the development efforts of the region. To date, African countries have not been suc- cessful in attracting significant FDI flows, reflecting largely the combined effects of political and macroeconomic instability, weak infrastructure, poor governance, inhospitable regulatory environments, intensification of competition for FDI flows due to globalization, and poor marketing strategies (Asiedu, 2008).

There is, therefore, the need to reverse the declining FDI trend in Africa. This requires concerted efforts at the national, regional, and international level. It also requires a new and more effective approach to investment promotion (Basu and Srinivasan, 2008).

There is a limited literature dealing with issues related to FDI flows to Africa (Abraham, 2009; Akinlo, 2008; Akyut and Datha, 2008; Aryeetey and Udry, 2010; and BendeNabande, 2005). However, the existing literature focuses on the empirical determinants of FDI to the region, with very little discussion of negotiation strategies that could be adopted to promote FDI flows to the region. The present paper attempts to overcome this limitation. It shall provide information on how to negotiate for FDI and emphasizes a new approach to the promotion of investment to the region that is based on improving relations with existing investors rather than focusing exclusively on costly activities of Investment Promotion Agencies. Furthermore, it identifies clearly what needs to be done at the national level to enhance FDI flows to Africa.

It is very important for governments to know how to negotiate for FDI. Anderson, Dimaranan, Francois, Hertel, Hoekman, and Martin (2011) provide two main reasons for this importance. The first is that globalization has increased the competition for FDI flows among developing countries. Since Africa is not one of the preferred destinations for investment among foreign investors, it is increasingly being recognized that actions by African countries would have to be complemented by efforts at the regional and international levels in order to improve the prospects for FDI flows to the region. Second, the New Partnership for Africa's Development (NEPAD) and the G8 "Africa Action Plan" call for a new relationship between African countries and their development partners that is based on shared responsibility for development effectiveness and outcomes (Aryeetey and Udry, 2010).

\subsection{Negotiation of FDI in Zimbabwe}

According to Hilltop and Udall (2008), negotiation is also an appropriate method of purchasing or selling where competitive bidding is impractical or when high value industrial or government contracts are involved in a long term. In this case the buyer's role shifts from being a sole negotiator to that of a negotiating team leader or the sales person's role shifts from being a sole negotiator to that of being a negotiating team sales leader.

A negotiating team is usually from two to eight members depending on the complexity of the deal to be negotiated and it is comprised of well experienced and knowledgeable people in various disciplines such as engineering, finance, purchasing and supply management as well as legal affairs. 
The negotiating team must have a leader who will be regarded as the chief negotiator who is responsible for coordinating various specialist opinions from a group of people who may view similar opinions differently. This leader must have the purchasing and supply expertise which he/she will use to integrate the various team members' skills and efforts into a single unit for successful negotiation. To accomplish this it is imperative that an overall strategy must be developed by the team and that each team member must be assigned a specific role to perform so as to contribute the successful negotiation of the intended deal (Abraham, 2009). For example in the Essar deal, the negotiating team should have been comprised with various experts from the relevant sister ministries aimed at achieving the same objective.

Moreover, the negotiating team through its chief negotiator must properly plan for its overall strategy by considering the following factors;

They must fully understand their economic objective interest in terms of sharing the commercial value.

They must understand the scope for information transparency and asymmetry since knowledge is power.

The ownership of risk and costs

The scope of opportunism, pre-and -post contractually

Understand the forms of economic power in terms resources brought into the contract

The above factors are very critical in achieving success in any deal to be negotiated. In both deals if the government negotiators had fully understood at length their economic objectives in terms of commercial value, they would not have entered into the negotiations suffering from a form of economic false consciousness. In the end they were now crying foul based on this wishful thinking, "If I had known what I now know I would not have entered into the contract". Meaning that they were now realising that they had been short changed into the contracted deals forcing them to back track and cry foul for their actions. The need to determine if the negotiators had the right information against their opponents is also fundamental (Hilltop and Udall, 2008). This is because naturally in any business deal a member of an organisation has to obtain the maximum benefit at the expense of the other party through the information being skewed in his favour in order to make a correct decision. For example in the Essar deal probably the buyers had the critical information that the Zimbabwean Government was so desperate to resuscitate the giant Steel Company hence made an offer which the negotiators accepted as being fair while the opposite was true.

According to Abraham (2008), the objective or motive of entering into an investment deal is to benefit either materially or in monetary terms and this is determined by identifying where the ownership of risk and costs lies most. It is therefore important to get this information from the specialist team members who will have been delegated to work so that their findings contribute positively to the negotiated deal. After considering the planning factors, the negotiating team must now evaluate all the relevant data and carefully assess their own strengths and weaknesses as a supplier against their opponents (buyer). This will help to determine and understand the forms of economic power in terms of resources brought into the contract. In addition to that, this will help the negotiators to adopt the most appropriate strategy when negotiating. For example in both deals the fact that the Zimbabwean negotiators owned the critical resources which were to be negotiated meant that they should not have been in a compromising position.

As a matter of fact, the consideration of the mentioned factors showed that when two separate legal entities come together for the purpose of working together through negotiation. There is always a possibility of conflict and tension in order to achieve their individual commercial goals (opportunism) which means that it is very difficult for someone to obtain a fair deal based on win- win situations because of imperfect information provided by both or either one of the parties.

\section{Research Methodology}

This study adopted a qualitative research design because it provided flexibility and afforded the researcher the opportunity to conduct an in-depth research. According to Saunders et al (2009) there are five research strategies underpinning qualitative research design. These include: experiment, survey, qualitative research, case study, and action research. For this research, case studies of Essar and Green Fuel FDI deals were conducted. Case studies allowed the researcher to conducted detailed analyses of the two FDI investments.

The population for this study was made up of six institutions, which were Green Fuel, Zimbabwe Steel Company, Zimbabwe Investment Centre (ZIA), Agricultural Development Authority (ARDA), Ministry of Industry and Commerce, and Ministry of Mines and Mining Development. Green Fuel and Zimbabwe Steel Company were the two cases analysed. ZIA is the entry point, into Zimbabwe, of all investors; therefore the institution had to be part of population elements. ARDA's inclusion in the population was premised on the fact that Green Fuel project was implemented on their land. Ministries of Industry and Commerce, and Mines and Mining Development were key stakeholders in Essar Deal; hence they were part of the study population.

When selecting participants from the six institutions who were part of the study population, the researcher made use of non-probability (purposive) sampling technique as the participants were deliberately selected. There was selection of participants who were good prospects for required information. The sample was made up of 40 participants, 10 from Essar and 10 from Green Fuel. ZIA, ARDA, Ministry of Industry and Trade, and Ministry of Mines and Mining Development provided a total of 20 participants, five from each institution.

The researcher made use of interviews as research instruments. Interviews provided a multi-perspective under- 
standing of the issues under investigation and they had the potential to reveal multiple, and sometimes conflicting, attitudes about a given topic (Marczyk, DeMatteo, and Festinger, 2005). The advantages of using an interview technique were that the respondents expanded on areas of interest and used non-verbal communication such as facial expressions to emphasise their responses. However, interviews were time consuming and expensive to conduct, and they involved protocol in setting up appointments and being granted authority to conduct them.

Data was analysed using content analysis. Ritchie and Lewis (2003) argue that qualitative content analysis involves a process designed to condense raw data into categories or themes based on valid inference and interpretation. The researcher made use of manual data coding system and the formal process of developing the coding scheme began shortly after the first few interviews. After coding the entire data set, the researcher rechecked the consistency of coding. It was not safe to assume that, if data was coded in a consistent and reliable manner, the coding of the whole corpus of text was also consistent. Human coders are subject to fatigue and are likely to make more mistakes as the coding proceeds (Kothari, 2004). For all these reasons, the researcher had to recheck coding consistency. After rechecking coding consistency, the researcher made inferences and present reconstructions of meanings derived from the data.

\section{Findings}

\subsection{Importance of Negotiation in FDI Deals}

The study showed that negotiation in FDI deals was vital because the negotiator's main object was to reach a beneficial agreement. It was also held that negotiation facilitates generation of new information and this allows negotiators to provide advice to their principals. Negotiations also facilitate communication between investors and host countries.

\subsection{Negotiation Processes for Essar and Green Fuel Projects}

\subsubsection{Essar Deal}

The bidding process for the tender of ZISCO culminated in the signing of an agreement between the Government of Zimbabwe and Essar Africa Holdings Limited of Mauritius in March 2011. The Agreement provided for a shares ownership structure of 54: 35:11 percent for Essar Africa Holdings Limited, the Government of Zimbabwe and Minority shareholders, respectively. In addition to that, Essar Africa Holdings Limited was required to inject an initial amount of US\$750 million in fresh capital towards the revival of ZISCO

Essar Africa Holdings Limited took over the Government of Zimbabwe's ZISCO related (internal and external) debt obligations amounting to approximately US\$340 million. The Government of Zimbabwe was set to benefit from the Agreement through the resumption of operations at the steel plant, which would provide raw materials for the local manufacturing industry. About 3000 jobs of the employees at ZISCO were to be saved and the benefits would cascade to the families of the employees.

However, in 2012, the Essar FDI deal was saddled in a lot of controversy, with the Ministry of Mines and Mining Development claiming that Essar were not going to pay a fair value for the resources they were going to take over. Mines and Mining Development Minister Dr Obert Mpofu said that the deal must be revisited because the Indian company would only pay US\$700 million for resources worth US\$30 billion. He says he will transfer mineral rights of ore to Essar only for actual value. Accordingly, the Ministry of Mines and Mining Development had not transferred the Buchwa Mine, Ripple Creek and Mwanesi iron ore mining rights to Essar Africa Holdings as at 28 May 2012. This was the major delaying factor to the conclusion of the agreement and the reason behind the salary freeze for the New Zimbabwe Steel Limited workers.

From the above findings, the researcher deduced that there was no stakeholder consultation before the FDI deal with Essar was signed. It seemed as if negotiators were in a hurry to sight the agreement before doing a thorough analysis.

\subsubsection{Green Fuel Project}

Green Fuel is a joint venture between the Government of Zimbabwe through the Agricultural Rural Development Authority and Macdom Investments in Chisumbanje. The US\$600 million Ethanol Project started operating in August 2011. The Green Fuel ethanol project was designed for the benefit of Zimbabwe and its people. By all accounts, Zimbabwe's economic recovery required innovative, sustainable and inward-looking projects. Ethanol production is one such, with the potential to provide economic development opportunities, stimulate job-creation, tax base diversification and new capital investments.

Domestic ethanol production can aid economic recovery and provide a domestic, cost-effective alternative to imported oil. Ethanol production can stimulate economic activity at the local and national level. The study found out that Green Fuel's Chisumbanje project has a daily ethanol production of 700000 litres and 18 megawatts of electricity which can be pumped back into the national grid. The project has created 4500 , largely local, jobs and is estimated to create 10000 more jobs by 2014 . With an unemployment rate above 75 percent, a significant handicap to Zimbabwe's recovery is a briefcase economy with fewer tangible job-creation opportunities at this scale.

Nevertheless, just like the case of Essar, there were challenges stalling Green Fuel project. The first challenge had to do with mandatory blending of fuel. There was slow uptake of ethanol by oil companies and this resulted in Green Fuel sitting on 8 million litres of ethanol in their storage facilities. This led to a temporary shut-down of the ethanol plant in early 2012.

Another challenge was that the government of Zimbabwe wanted the project to be transformed from a BOT to 
a joint venture with Zimbabwe having 51\% while Madcom retained $49 \%$. This move seemed to drive potential investors away due to 'shifting of goal posts' by Zimbabwean authorities.

The case of Green Fuel, again, demonstrated absence of wide stakeholder consultation before implementation of the project. There was evidence of lack of transparency on the part of host government.

\subsection{Strategies for Improving Negotiation for FDI in Zim- babwe}

There was a need to improve FDI negotiation in Zimbabwe. The researcher believed that, in order to carry out the identified tasks, successfully, the negotiators must have the following skills, that is, social interpersonal skills, information handling skills, discretionary judgment skills, sensitivity, timing, foresight, and persuasiveness.

Social interpersonal skills allow the negotiators to recognize, interpret and utilize both the verbal and non-verbal communications that are an essential part of any negotiation. The negotiators must pay close attention, not only to what the other party says, but also to the manner in which 'it is said' and equally to what 'is not said'. It is these 'clues' which aid the negotiator to interpret and assess the attitudes and strength of feeling of the other party and, from this, make judgment as to what is, and is not, important within the context of that negotiation.

The negotiators must have information on handling skills, they must be fully conversant with the issues under negotiation and the context within which discussions are to take place. In the initial preparation phase, the negotiators must decide what information will be required, how it is to be presented and within what framework of argument and justification. During the negotiating encounter, the negotiators must have sufficient knowledge and flexibility in its use to be able to respond readily to points or counter arguments raised by the other party.

The negotiators should have discretionary judgment skills, and must make judgments regarding the implementation of the predetermined strategy and, in particular, determine when and how changes in argument and position should take place. The authorities should be able to judge and estimate whether the solution is the best that could be reached in the circumstances and assess, whether it will be acceptable to the parties represented.

Negotiators should be persuasive or interactive. This is extremely important in any negotiation scenario. In fact, effective persuaders use a strategy of persuading people to accept and become committed to their desired outcome. It involves developing the other person's need for the desired outcome so that it outweighs the cost of non-acceptance.

Moreover, negotiators need to remember that bargaining, by its very nature, is part of a compromise process. There is no such thing as having all the 'pie'. There is also a need to consider the impact of present negotiations on bargaining the future years. Precision of language in negotiation is important to ensure understanding. One should consider the
A.B.C. of communication that is, accuracy, brief, and clear. However, ambiguity or fudging can sometimes play a constructive role in negotiation, especially when parties agree on the more important issues confronting them.

In addition, the negotiating teams through chief negotiators needed to properly plan for its overall strategy by considering the following factors. They must prepare carefully for the negotiation, in this case for the Green Fuel Ethanol Deal and the Essar Deal. The Ministry of Industry and Commerce which is the leading negotiator on behalf of the Government of Zimbabwe must have planned in collaboration with its sister ministries who are the critical cross functional team members or stakeholders. These include the Ministry of Mines, the Ministry of Agriculture, Ministry of Finance, Ministry of Environment and the Ministry of Regional Integration and International Cooperation, as well as expects from the Ministry of Justice and Legal Affairs. This team is expected to be well prepared in establishing the technical and commercial aspects of what is to be negotiated, that is they must fully understand their economic objective interest in terms of sharing the commercial value. To determine the level of appetite of the FDI in getting involved in the contract, to conduct a price or cost analysis so as to ascertain the level of risk involved. They must understand the scope for information transparency and asymmetry since knowledge is power. The scope of commercial opportunism, pre-and -post contractually by the partners and to understand the forms of economic power in terms resources brought into the contract. For example, this could have avoided the unexpected reaction by the Ministry of Mines to refuse to award the mining claims to the foreign investor claiming that it was not involved in the negotiation of the deal and it was not happy with the sharing structure. In the Green Fuel Deal the stalemate could also have been avoided if the leading negotiator the Ministry of Energy and Power Development could have involved the other critical stakeholders or ministries as explained previously in the Essar deal. For instance the fact that the government of Zimbabwe is no longer interested in utilising the product negotiated under the Green Fuel Deal and that they were yet still to agree on the outstanding issues concerning the structure of the fundamentals of the deal shows how ill prepared they were when they negotiated the deal.

The above factors are very critical in achieving success in any deal to be negotiated if the government negotiators had prepared themselves fully by engaging the necessary stakeholders in sharing ideas. But because they were not well prepared they entered into the negotiations suffering from a form of economic false consciousness. In the end they were now crying foul based on this wishful thinking, "If I had known what I now know I would not have entered into the contract". Meaning that they are now realising that they were short changed into the contracted deals forcing them to back track and cry foul for their actions. The need to determine if the negotiators have the right information against their opponents in also fundamental. This is because naturally in any business deal a member of an organi- 
sation has to obtain the maximum benefit at the expense of the other party through the information being skewed in his favour in order to make a correct decision. For example in the Essar deal probably the buyers had the critical information that the Zimbabwean Government was so desperate to resuscitate the giant Steel Company hence made an offer which the negotiators accepted as being fair while the opposite was true.

The objective or motive of entering into an investment deal is to benefit either materially or in monetary terms and this is determined by identifying where the ownership of risk and costs lies most. It is therefore important to get this information from the specialists team members who will have been delegated to work so that their findings contribute positively to the negotiated deal.

After considering the planning factors, the negotiating team must now evaluate all the relevant data and carefully assess their own strengths and weaknesses as a supplier against their opponents (buyer). This will help to determine and understand the forms of economic power in terms of resources brought into the contract. In addition to that, this will help the negotiators to adopt the most appropriate strategy when negotiating. For example in both deals the fact that the Zimbabwean negotiators owned the critical resources which were to be negotiated meant that they should not have been in a compromising position.

As a matter of fact, the consideration of the mentioned factors shows that when two separate legal entities come together for the purpose of working together through negotiation. There is always a possibility of conflict and tension in order to achieve their individual commercial goals (opportunism) which means that it is very difficult for someone to obtain a fair deal based on win- win situations because of imperfect information provided by both or either one of the parties. However Cox et al (2004) outlines the scope of opportunism in different types of business relationship which negotiation parties should be aware of before signing the deal as this can help them to know their positions better. As a result, if the writer was to be involved in the negotiation process of the deals under discussion he would contribute his views as in table 1 .

Table 1. Types Of External Business Relationships.

\begin{tabular}{|c|c|c|}
\hline \multirow{2}{*}{$\begin{array}{l}\text { The Characteristics } \\
\text { Of The Exchange Strategies }\end{array}$} & \multicolumn{2}{|l|}{ Horizontal Relationships } \\
\hline & Joint Venture & Strategic Alliance \\
\hline $\begin{array}{l}\text { Basic definition } \\
\text { Of the } \\
\text { Relationship }\end{array}$ & $\begin{array}{l}\text { Two legal separate parties remain independent, } \\
\text { but create a new company that they both jointly } \\
\text { own and manage to produce and sell products } \\
\text { and /or services together in the market. }\end{array}$ & $\begin{array}{l}\text { Two legally separate parties remain independent, but enter into an } \\
\text { agreement to corporate to achieve specific commercial and opera- } \\
\text { tional objectives by working together to produce and/or market } \\
\text { and sell a product and/or service together in the market. }\end{array}$ \\
\hline $\begin{array}{l}\text { Typical sharing of } \\
\text { value in the relationship }\end{array}$ & $\begin{array}{l}\text { Can be full or preferential-equity based share } \\
\text { ownership can be equitable }(50 / 50) \text { or } \\
\text { majority /minority. The issue of power in the } \\
\text { relationship post contractually is legally defined } \\
\text { by the shareholders agreement. }\end{array}$ & $\begin{array}{l}\text { There is no necessary fixed agreement on how value is shared in } \\
\text { the relationship.' This is still negotiable and could be close to zero } \\
\text { sum }(99 / 1) \text { or positive sum }(50 / 50) \text { depending on the relative e } \\
\text { power attributes to the two parties. }\end{array}$ \\
\hline $\begin{array}{l}\text { Scope for information } \\
\text { transparency or asymmetry }\end{array}$ & $\begin{array}{l}\text { Normally high levels of actual and potential } \\
\text { information transparency for both parties due to } \\
\text { share holding, but preference shareholders may } \\
\text { be to hide or delay information about tradeoffs } \\
\text { between some operational activities and } \\
\text { commercial outcomes. }\end{array}$ & $\begin{array}{l}\text { The degree of information transparency about commercial trade- } \\
\text { offs is a function of what is negotiated in a specific alliance } \\
\text { agreement. High levels of information asymmetry are possible as } \\
\text { well as transparency. }\end{array}$ \\
\hline $\begin{array}{l}\text { Ownership of reward } \\
\text { risks and costs of operations }\end{array}$ & $\begin{array}{l}\text { Both parties jointly share all of the risk and } \\
\text { costs of operations relative to share ownership, } \\
\text { an d both have transparency over the rewards that } \\
\text { arise if the company is successful. The level and } \\
\text { type of share ownership may vary the reward } \\
\text { outcome for each party. }\end{array}$ & $\begin{array}{l}\text { Each party carries their own risks and costs of operation, and } \\
\text { receives their own rewards as negotiated. Whether or not there is } \\
\text { full transparency over the rewards received by the other party } \\
\text { depends on what has been negotiated. Whether or not there is full } \\
\text { transparency over the rewards received by the other party depends } \\
\text { on what has been negotiated. }\end{array}$ \\
\hline $\begin{array}{l}\text { Scope for opportunism } \\
\text { for either party }\end{array}$ & $\begin{array}{l}\text { Opportunism within the jointly owned company } \\
\text { is limited. There may be some scope for } \\
\text { opportunism from preferential shareholding. } \\
\text { Each party can be opportunistic about the } \\
\text { benefits of other businesses from participation } \\
\text { in the joint venture. }\end{array}$ & $\begin{array}{l}\text { A dominant party in the alliance can often be opportunistic against } \\
\text { the more dependent party. The scope for opportunism by both } \\
\text { parties is only limited by what has been agreed in the alliance } \\
\text { agreement and even dependent parties may be able to hide the } \\
\text { true rewards they receive. }\end{array}$ \\
\hline
\end{tabular}


After concluding the deal the negotiating parties (the Zimbabwean Government and its Partners) should know the operational or commercial outcome of the deal so that its survival is not threatened by one of the parties backtracking. Again Cox (2004) went on to explain the results of the negotiated deal as in table 2 .

Table 2. Results of Negotiated Deal

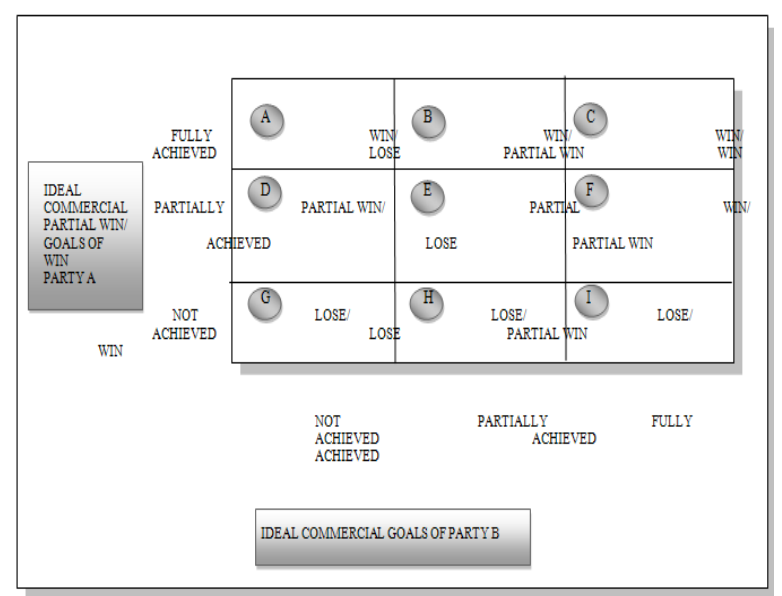

There are nine possible commercial outcome scenarios which the negotiating parties should expert and these are interpreted as follows. Category $\mathrm{A}$ is a win-lose situation which means negotiating party A achieves everything while party B losses everything he values commercially. Category $B$ is win-partial win, party $A$ achieves everything he values commercially while B partially achieves the commercial value. Category $C$ this is a win -win situation where both parties $\mathrm{A}$ and $\mathrm{B}$ achieves fully all the things they value from the commercial relationship. In category $\mathrm{D}$, part $\mathrm{A}$ partly achieves something commercially and B achieves nothing at all. Category E, in this case both parties partially achieves something but not what they expected commercially. In category F, A achieves part of what he values commercially while B fully achieves what he values commercially. In category $\mathrm{G}$, this is when both negotiating parties fail to achieve anything they value commercially from the relationship being a lose-lose situation. Category $\mathrm{H}$, this is where A fails to win anything that is of commercial value while $B$ achieves some of the things that he values, this is a lose- partial win outcome. Finally in category I, part A does not achieve anything of commercial value from the relationship and B fully achieves his ideal commercial objectives and this is will be a lose-win situation outcome. As a result this analysis shows that if the Zimbabwean negotiators had strategically considered the discussed factors objectively. They would have entered into the negotiations knowing the possible outcome of their economic objective interests and be prepared how to manage the relationship without crying foul and the writer would not be in a position to consider negotiation as a threat to Zimbabwean investment deals.

\section{Conclusion and Recommendation}

\subsection{Conclusion}

This study showed that there were some flaws in the negotiations for FDI in Zimbabwe. Admittedly, Zimbabwe was negotiating under immense pressure because of the economic sanctions. Negotiators were tempted to do certain favours for those friends who had stood by them in difficult times. So some of the decisions must be understood and accepted in that context as long as they were reasonable.

\subsection{Recommendations}

\subsubsection{Transparency}

It is vital that Zimbabwean negotiators to FDI deals be transparent to investors and provides them with all the information about investment laws in Zimbabwe. A situation in which there are adjustments to FDI investments because certain legal requirements were overlooked is not advisable.

\subsubsection{Wide Stakeholder Consultation}

There is need for wide stakeholder consultation during FDI negotiations. For instance, how was it possible that Essar deal could be signed without the involvement of the Minister of Mines and Mining Development, who happens to sit in Cabinet where such matters are discussed?

\subsubsection{Taking Time to Analyse Deals Before Signing Agreements}

Negotiators need to be more thorough before making decisions about how national resources are being exploited by foreign investors who would have come to partner the Government at its invitation. There is no need to rush in signing deals.

\section{References}

[1] Akingube O. (2008), Flow of Foreign Direct Investment to Hitherto Neglected Developing Countries, Discussion Paper, Helsinki.

[2] Akyut, D. and Ratha, D. (2008), South-South Foreign Direct Investment Flows: How Big Are They? Third World Network, Geneva.

[3] Abraham, T. (2009), Reviving an Old Dream of Afro-Asian Cooperation, Yale Global, New Delhi.

[4] Akinlo, A. E. (2008), Foreign Direct Investment and Economic Growth in Sub-Saharan Africa, International Review of Economics and Business.

[5] Anderson, K., Dimaranan, B., Francois, J., Hertel, T., Hoekman, B., and Martin, W. (2010), The Cost of Rich Country Protection to Developing Countries, Journal of African Economies 10.

[6] Aryeetey, E. and Udry, C. (2010), Saving in Sub-Saharan Africa, Harvard Center for International Development, 
Working Paper No. 38.

[7] Asiedu, E. (2008), Aggressive Trade Reform and Infrastructure Development: A Solution to Africa's Foreign Direct Investment Woes, Department of Economics, University of Kansas.

[8] Basu, A. and Srinivasan, K. (2008), Foreign Direct Investment in Africa: Some Case Studies, International Monetary Fund Working Paper, WP/08/61.

[9] Bende-Nabenfe, A. (2005), Foreign Direct Investment Determinants in Sub-Saharan Africa: A Cointegration Analysis, Economics Bulletin 6.

[10] Cox, A. (2004), Win-Win? Earlgate Press, UK.

[11] Hilltop, J.M. and Udall S. (2008), The Essence of Negotiation, Prentice Hall New Jersey.
[12] Kothari, C.R. (2004), Research Methods and Techniques, New Age Publishers, New Delhi.

[13] Marczyk, G., DeMatteo, D. and Festinger, D. (2005), Essentials of Research Design and Methodology, John Wiley and Sons, New Jersey.

[14] Moss, T., Ramachandran, V., and Shah, M. (2008), Is Africa's Skepticism of Foreign Capital Justified? Evidence from East African Firm Survey Data, Center for Global Development, Working Paper No. 41.

[15] Ritchie, J. and Lewis, J. (2003), Qualitative Research in Practice, A Guide for Social Sciences Students and Researches, Sage Publishing, New Delhi.

[16] Saunders, M., Levin, P., and Thornhill, A. (2009), Research Methods for Business Students, Fifth Edition, Prentice-Hall, London. 